\title{
THE THEORETICAL ESSENCE AND THE IMPORTANCE OF INTELLECTUAL PROPERTY IN THE ACTIVITIES OF DOMESTIC ENTERPRISES
}

\author{
Shcheblykina I.A., *Shcheblykina Z.V., Grinberg I.A. \\ Zaporizhzhia National University \\ Ukraine, 69600, Zaporizhzhia, Zhykovsky str., 66 \\ * Bogdan Khmelnitskiy Melitopol State Pedagogical University \\ Ukraine, 72300, Melitopol, Getmanska str., 20 \\ innasheblykina@gmail.com

\section{ORCID 0000-0002-4886-5850}

Key words:

intellectual property, material assets, intellectual property.
The study is devoted to the study of the theoretical essence and significance of intellectual property in domestic enterprises. The interpretation of intellectual property by domestic and foreign scientists is considered, the properties of intellectual property are studied, the role of intellectual property as an independent economic object capable to be of benefit and income to its owner is substantiated, the classification of intellectual property is considered. It has been determined that intellectual property has properties that are inherent in both intangible assets and those that are distinctive features of intellectual property. The characteristics of intellectual property include the fact that they are factors in the creation and development of a competitive environment and the results or manifestations of creative mental work of people, that make new, original ideas, knowledge, information. It has been noted that one of the main and most valuable features that distinguishes the studied category from other materials assets is the inexhaustibility of intellectual capital, which consists of the structure of intellectual property, knowledge and experience of the organization's staff and others. The study found that by participating in economic relations, intellectual property acts as an independent economic object that can bring benefits and income to the owner. It is important to study an intellectual property not only as a result of activity, but also as a powerful tool in brutal competition. It has been noted that one of the main problems regarding intellectual property in the enterprise is the evaluation and accounting of intellectual property.

The very important prerequisite for assessing the value of intellectual property are its inclusion in innovative and investment projects; in the case of expanding markets; determination of damage caused by improper use of intellectual property, etc. It can be concluded that material assets as a form of intellectual property are rights or benefits in the long run, which were acquired by the owner and reflected in the balance sheet of the enterprise at the price of their acquisition and bringing to business.

\section{ТЕОРЕТИЧНА СУТНІСТЬ ТА ЗНАЧЕННЯ ІНТЕЛЕКТУАЛЬНОӤ ВЛАСНОСТІ В ДІЯЛЬНОСТІ ВІТЧИЗНЯНИХ ПІДПРИЕМСТВ}

\author{
Щебликіна I.O., Грінберг I.O. \\ Запорізький національний університет \\ Україна, 69600, м. Запоріжжя, вул. Жуковського, 66
}

\section{Ключові слова:}

інтелектуальна власність, нематеріальні активи, об'єкти інтелектуальної власності.
Дослідження присвячено вивченню теоретичної сутності та значення інтелектуальної власності на вітчизняних підприємствах. Розглянуто трактування інтелектуальної власності вітчизняними та зарубіжними науковцями, досліджено властивості об'єкті інтелектуальної власності, обгрунтовано роль інтелектуальної власності як самостійного економічного об'єкту, здатного приносити користь та дохід його власнику, розглянуто класифікацію об'єктів інтелектуальної власності. Визначено, що об'єкти інтелектуальної власності мають властивості, що притаманні як нематеріальним активам, так $\mathrm{i}$ ті, що є відмінними рисами об'єктів інтелектуальної власності. До властивостей саме об'єктів інтелектуальної власності відносить те, що вони є чинниками створення та розвитку конкурентного середовища та результатами або проявами творчої розумової праці людей, що становить нові, оригінальні ідеї, знання, інформацію. Зазначено, що однією з головних і найцінніших ознак, що відрізняє досліджувану категорію 3-поміж інших матеріальних активів, є саме невичерпність інтелектуального капіталу, який за структурою складається 3 об'єктів інтелектуальної власності, знань та досвіду персоналу організації тощо. В процесі дослідження визначено, що приймаючи участь у економічних відносинах, інтелектуальна власність виступає як самостійний економічний об'єкт, що здатний приносити користь та дохід власнику. Інтелектуальну власність актуально 
досліджувати не тільки як результат діяльності, а саме як потужний інструмент у жорсткій конкурентній боротьбі. Зазначено, що однією 3 найголовніших проблем, відносно інтелектуальної власності на підприємстві, є оцінка та облік об'єктів інтелектуальної власності. Дуже важливими передумовами для оцінки вартості інтелектуальної власності $\epsilon$ внесення іï до інноваційних та інвестиційних проектів; у разі розширення ринків збуту; визначення збитку, завданого неправомірним використанням об'єктів інтелектуальної власності тощо. Можна зробити висновок, що нематеріальні активи як форма вияву інтелектуальної власності - це права або переваги у довгостроковому періоді, які були придбані власником i відображені у балансі підприємства за ціною їх придбання та доведення до комерційної діяльності.

\section{Statement of the problem}

In the market economy, effective management of intellectual property is one of the most important tools for dynamic growth and development of any enterprise by creating opportunities for the latter to gain significant advantages in terms of increasing product competitiveness, improving image, reducing production costs, using new technologies, etc.

The strategy of innovative development of Ukraine's economy in modern conditions should be based, in particular, on improving the intellectual property management process of domestic businesses, as Ukrainian enterprises need innovative development, which would be accompanied by significant changes in technological processes, material and energy consumption. This highlights the need for a deeper study of nature, role and principles of intellectual property management in domestic enterprises in a market environment of management.

\section{Analysis of recent studies and publications}

In modern conditions, intellectual property acquires the role of a basic asset, which is able to bring the company additional income, increase its market value, increase competitiveness and intensify foreign economic activity. In this regard, the problems of improving the management of intellectual property are highlighted in the works of domestic scientists, such as: K.I. Dmitriv, Z.B. Zhivko, P.M. Tsibulova, V.P. Chebotareva, A.I. Kubakh, A.P. Pukhalskaya and others.

Among foreign scholars who have devoted their work to the study of theoretical and applied principles of intellectual property management, it is necessary to highlight the work by G.G. Azgaldov, V.D. Bazilevich, A.A. Bovin, V.G. Zinov, A.M. Kozirev, G.M. Desmond, N.M. Karpova, P.E. Keli, P.B. Meggs, G.I. Olekhnovich, A.P. Sergeev, T.A. Styuart, B. Khirosaki and others. Despite the significant contribution of these scientists, it should be noted the need for further research on improving the management of intellectual property in domestic enterprises. In addition, today in the economic literature there is no comprehensive justification for defining the category of «intellectual property», which, in turn, causes some misunderstandings and requires more attention from the study of its essence and features.

\section{Objectives of the article}

Given the above, the objective of this study is to study the importance of intellectual property and its objects for domestic enterprises and to improve the theoretical essence of this economic category.

\section{The main material of the research}

For the first time in Ukraine, the right to own and use the results of one's intellectual creative activity was enshrined in Art. 41 of the Constitution of Ukraine.

Considering the concept of «intellectual property», it should be noted that it is quite multifaceted and complex. In particular, it should be noted that the category «intellectual property» is widely used in conjunction with such categories as «intellectual capital» and «intangible assets». However, most existing definitions of «intellectual property» reveal the legal meaning of this concept.

So, O.B. Butnik-Siverskiy, A.P. Gavrilenko, S.A. Dovgiy and others define intellectual property as the result of virtual in nature, creative, intellectual work. Scientists point out that there is no strict scientific definition of the category and interpret intellectual property as «a set of rights to an intellectual product that is the result of creative efforts and has meaning for a certain, intellectually prepared circle of people» [3, p. 12].

Ukrainian researchers P.M. Tsibulov, V.P. Chebotaryev characterize intellectual property as the right to the results of creative work and note that these rights consist of two branches: the personal non-property right of the creator to the result of intellectual work and property rights to this result (object of law) [11]. The allegations of these authors are based on the articles of the Civil Code of Ukraine, which set out the essence of personal non-property rights and intellectual property rights.

In his research, V.O. Potekhina expresses the opinion that at the present stage of development of market relations the main role is given to the value which is created on the basis of knowledge, that is intellectual property turns into the goods.

In her work, the researcher defines intellectual property as a set of rights to material assets that are the result of intellectual activity and have economic value. The main feature of the category is the possibility of free alienation, taking into account the protection and protection of these rights as the owner and society in the face of the state [7, p. 21].

Belarusian scientist G.I. Olekhnovich interprets intellectual property as «the right to the results of intellectual activity in all fields». That is, he evaluates this category, both as an object of law and as an abstract concept. It should be noted that in substantiating the essence of the concept of intellectual property, the position on the interpretation of it as a set of rights as a result of intellectual activity adhere to many scientists [6, p. 24].

Russian scientists P.B. Meggs, A.P. Sergeev interprets intellectual property by legal institutions of the state as a generalized concept in relation to a number of legal 
institutions, the most significant of which is the institution of trade secrets, patent law, copyright and trademarks [5].

Ukrainian researcher of intellectual property problems V.M. Antonov interprets it as the right to the results of human mental activity in scientific, artistic, industrial, information technology, computer and other fields. The object of civil law relations are the rights of the creator and user of intellectual property to own, use and dispose of the results of intellectual, creative activity [1, p. 11].

A.I. Kubakh interprets the category of intellectual property as a formalized result of creative intellectual activity, which gives its author or a person defined by current legislation, ownership of this result, which is acquired, exercised and protected in accordance with statutory norms and rules [4, p. 9].

One must take notice that in the above interpretations of this category, scientists do not pay much attention to the properties of intellectual property, the economic component and the effect observed in its commercialization.

Quite interesting and non-standard are the views of O. Rudenko, who considers intellectual property from an economic and accounting point of view in the form of expenditures on education or acquisition of intangible objects, which are carried out in order to increase capital [9, p. 76].

Also interesting is the definition given by foreign scholars W. Landes and R. Posner, who understand the category of «intellectual property» ideas, inventions, symbols, images, works of art (oral, visual, musical, theatrical), or, in short, any -which is a potentially significant human product (in a broad sense - «information»), which has an existence separate from the unique physical embodiment. This product can actually be «appropriated», that is, subject to the legal regime of property rights [12].

After analyzing the research of foreign and domestic authors, we can conclude that intellectual property has characteristics that are inherent in both non-material assets and those that are distinctive features of intellectual property. Thus, the Ukrainian researcher of intellectual property V.D. Bazylevich attributes to the characteristics of intellectual property objects that they are:

- factors in the creation and development of a competitive environment;

- the results or manifestations of creative mental work of people, which is new, original ideas, knowledge, information [2].

However, in our opinion, the works of domestic and foreign scientists do not pay enough attention to such an important feature of intellectual property as the fact that intellectual property has a monetary value and brings economic benefits to the owner. It is also worth noting that one of the main and most valuable features that distinguishes the studied category from other materials assets is the inexhaustibility of intellectual capital, which consists of the structure of intellectual property, knowledge and experience of the organization's staff etc. That is, for domestic enterprises in modern conditions there is an opportunity to effectively increase the intellectual potential and economic development, provided a competent and balanced use of this inexhaustible resource.
It should also be noted that the above significant number of interpretations of the essence of intellectual property from the standpoint of legal science suggests that the generally accepted and the most common definition of the essence of the category is this approach. It should be noted that, participating in economic relations, intellectual property acts as an independent economic object that can bring benefits and income to its owner. At the same time, it is relevant at present to consider intellectual property not as a result of activity, but as a powerful tool in fierce competition.

At the moment, one of the main problems related to intellectual property in the company is the evaluation and accounting of intellectual property. In order to use the objects of this property, the company must credit it to the balance sheet, so in accounting, intellectual property is indicated as material assets.

Material assets are divided according to the relevant characteristics and classified according to the content of the right, the term of use and the nature of ownership. According to the recommended classification, depending on the content of the law, intellectual property can be divided into those that have copyright, related rights, patents and legal means of individualization of participants in civil turnover, goods and services. According to the term of use, are divided into capitalized costs, namely, trade secrets and other types of costs, with a definite and without a definite term of use. By the nature of possession, they are divided into those that have the exclusive right of possession and non-exclusive one. We can conclude that material assets as a form of intellectual property are rights or benefits in the long run, which were acquired by the owner and reflected in the balance sheet of the enterprise at the cost of their acquisition and commercialization. A very important prerequisite for assessing the value of intellectual property is its inclusion in innovative investment projects in the case of expanding markets and insurance, transfer of intellectual property as collateral for the purpose of obtaining loans; determination of damage caused by improper use of intellectual property; in case of bankruptcy of the enterprise in the process of its liquidation in order to satisfy creditors' claims; inclusion of intellectual property in the authorized capital; calculation of the price for the right to use the object of intellectual property rights through the conclusion of a license agreement; determining the amount of royalties; obtaining a bank loan secured by exclusive intellectual property rights; drawing up a business plan to attract investment; determining the amount of income tax when it is donated; determination of damages from infringement of intellectual property rights.

The main source of growth in the value of companies is the growth of the value of intellectual capital, which is formed on the basis of commercialization of intellectual property and other non-material assets [5, p. 17]. That is why we consider providing a classification of intellectual property, which specifies the types and groups of intellectual property depending on the main ways of commercialization of intellectual property in the enterprise (Fig. 1) [8].

Listed in Fig. 1 classification of intellectual property objects characterizes them from the standpoint of the type of object, the method of commercialization and the method of receipt of the object in the enterprise. 


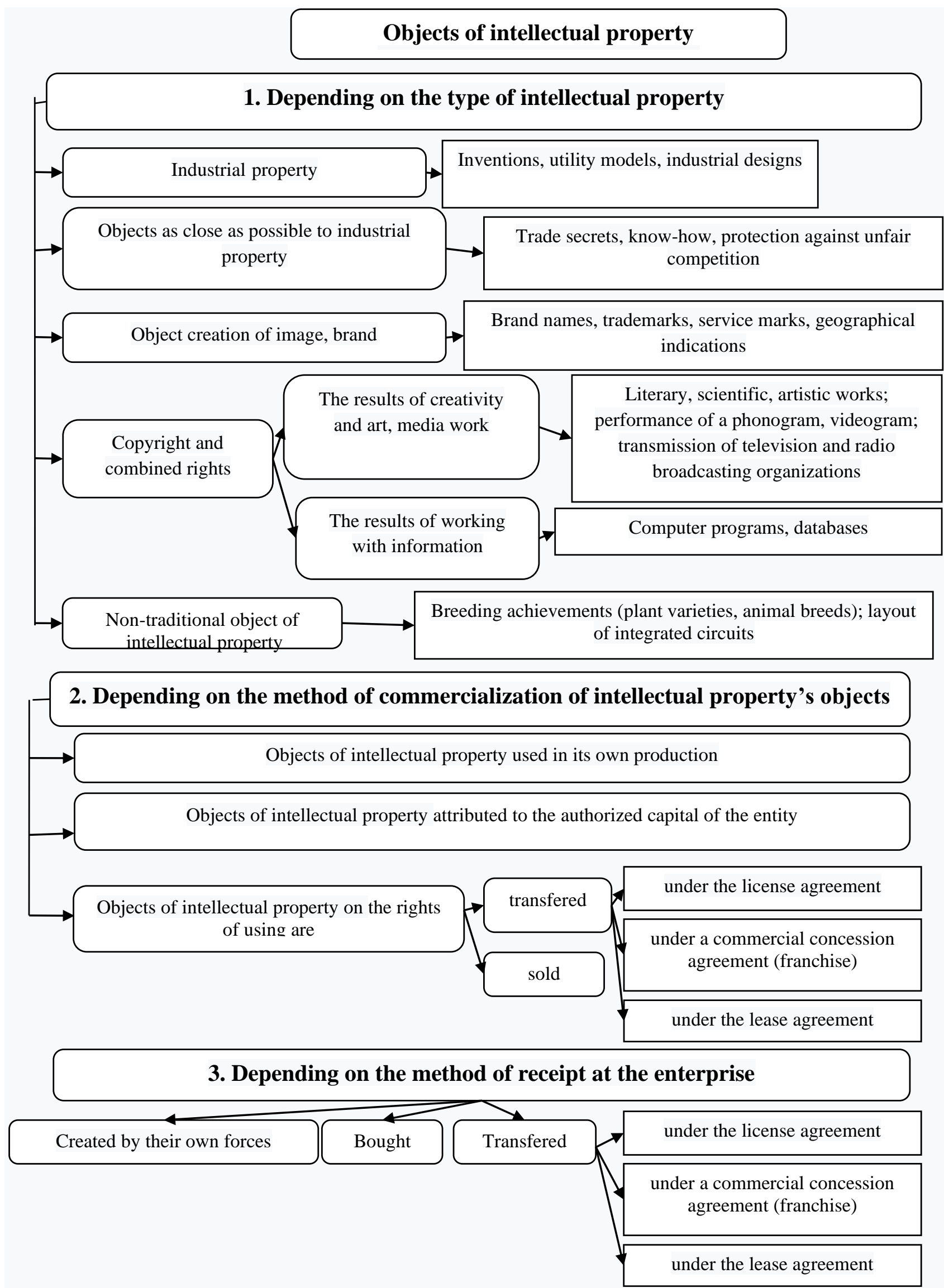

Fig. 1. Classification of objects of intellectual property [8] 
According to the recommended classification, depending on the type of intellectual property, there are objects of industrial property (inventions, utility models, industrial designs), objects as close as possible to industrial property (trade secrets, know-how, protection from unfair competition), objects of image creation, brand (brand names, trademarks, service marks, geographical indications), copyright and related rights (among which there are results of creativity and art - literary, scientific, artistic works, performance of phonograms, videograms, and radio broadcasting, media works and results of work with information - computer programs, databases) and non-traditional objects of intellectual property (selection achievements, layout of integrated circuits).

Depending on the method of commercialization, intellectual property is divided into objects used in their own production, attributed to the authorized capital of the entity and objects which rights to use are transferred (under a license agreement, a commercial concession agreement or under the lease agreement) or sold.

Depending on the method of receipt of the enterprise, objects of intellectual property are classified into objects created by their own forces, purchased and transferred (under a license agreement, under a commercial concession agreement, under a leasing agreement).

Note also that the economic essence of intellectual property is a part of the most important economic resource - intellectual [2]. This resource is renewable and is crucial in intensifying the development of any business entity, as it opens up opportunities for fair competition. An economic category of intellectual property is when it is valued, recorded in accounting and financial reporting as a material asset used in economic activities (for example, the introduction of intellectual property rights to the authorized capital of the enterprise).

Researcher A.O. Trofimishina emphasizes another side of intellectual property - that is intellectual property should be considered from a psychological point of view [10]. She added that the feeling of ownership of intellectual resources means not only power, improving the status and image of the business entity in the eyes of competitors, but also the use of new motivational incentives in the process of personnel management, the possibility of opening new horizons.

\section{Conclusions}

Thus, examining the category of «intellectual property», it was found that domestic and foreign scientists have not paid enough attention to the economic nature of these assets, that is their ability to commercialize in the process of economic turnover.

A scientifically based classification of intellectual property objects is proposed, the application of which will allow enterprises in the process of economic activity to compare the efficiency of using different types of intellectual property objects and identify objects that need commercialization.

In general, it should be noted that domestic enterprises in order to ensure their competitiveness should focus on the production of high-tech products, as well as to create conditions that would facilitate the fastest introduction of these products. The use and protection of intellectual property will not only ensure the high competitiveness of products, but also to control the segment of the commodity market or industry.

\section{References}

1. Antonov, V.M. (2006). Intelektualna vlasnist i kompyuterne avtorske pravo [Intellectual property and computer copyright]. Kyiv: KNT [in Ukrainian].

2. Bazilevich, V.D. (2008). Intelektualna vlasnist [Intellectual property]. Kyiv: Znannia [in Ukrainian].

3. Butnik-Siverskiy, A.B., \& Svyatotskiy, A.D. (Ed.). (1999). Intelektualnaya sobstvennost v Ukraine: pravovie osnovi i praktika [Intellectual property in Ukraine: legal framework and practice]. (Vols. 1-4). Kyiv: InYure [in Russian].

4. Kubakh, A.I. (2008). Pravo intelektualnoi vlasnosti [Intellectual property rights]. Kharkiv: KHAMG [in Ukrainian].

5. Meggs, P.B. \& Sergeev, A.P. (2000). Intelektualnaya sobstvennost [Intellectual property]. Moskva: Yurist [in Russian].

6. Olekhnovich, G.I. (2005). Intelektualnaya sobstvennost i problemi eye kommertsializatsii [Intellectual property and problems of its commercialization]. Minsk: Amalfeya [in Russian].

7. Potekhina, V.O. (2008). Intelektualna vlasnist [Intellectual property]. Kyiv: Tsentr uchbovoi literaturi [in Ukrainian].

8. Pukhalska, A.P. (2013). Mekhanizm upravlinnya intelektualnoyu vlasnistyu pidpriemstv mashinobudivnoi galuzi [Mechanism of intellectual property management of machine-building enterprises]. Biznes Inform - Business Inform, 2, 128-134 [in Ukrainian].

9. Rudenko, O. (2004). Bukhgalterskiy oblik obektiv intelektualnoi vlasnosti [Accounting for intellectual property]. Spravochnik ekonomista - Economist's handbook, 12, 76-79 [in Ukrainian].

10. Trofimishina, A.O. (2010). Zmistovi osoblivosti uyavlen pro intelektualnu vlasnist u bikladachiv VNZ [Semantic features of intellectual property ideas in university teachers]. Problemi zagalnoi i pedagogighnoi psichologii - Problems of general and pedagogical psychology, 12, 574-583 [in Ukrainian].

11. Tsibulov, P.M., \& Chebotarev, V.P. (2004). Populyarno pro intelektualnu vlasnist:abetka [Popular about intellectual property: the alphabet]. Kyiv: TOV «Alfa-PIK» [in Ukrainian].

12. Landes, W.M., \& Posner, R. A. (2003). Ekonomichna struktura prava intelektualnoi vlasnosti [The economic structure of intellectual property law]. Harvard : Belknap Press of Harvard University Press [in English]. 